\title{
Produksi Maggot Lalat Tentara Hitam (Hermetia Illucens) Pada Lama Pemeliharaan Yang Berbeda
}

\author{
Andi Tenri Bau Astuti Mahmud, Santi \\ Program Studi Peternakan Fakultas Ilmu Pertanian Universitas Al Asyariah Mandar \\ Email : $\underline{\text { anditenribauastuti@gmail.com }}$ \\ santipeternakan@gmail.com
}

\begin{abstract}
Abstrak
Mahalnya harga pakan sumber protein hewani disebabkan bersaing dengan manusia. Tujuan penelitian ini adalah untuk mengoptimalkan produksi magoot meliputi ukuran maggot, berat basah dan berat kering maggot dengan lama pemeliharaan yang berbeda. Penelitian ini dilaksanakan pada bulan April - Juli 2019. Pemeliharaan maggot lalat tentara hitam Hermetia illucens, Penelitian ini dilaksanakan di Program Studi Peternakan Unasman untuk pemeliharaan dan analisis nutrisi di laksanakan di Lab Kimia Pakan Fakultas Peternakan UNHAS. Penelitian ini dirancang menggunakan Rancangan Acak Lengkap (RAL) 5 perlakuan yaitu lama pemeliharaan maggot dan 3 ulangan. Secara keseluruhan menghasilkan 15 kombinasi perlakuan, yaitu $5 \times 3$ unit percobaan dengan perlakuan yaitu $\mathrm{P}_{0}=5$ hari, $\mathrm{P}_{1}=10$ hari, $\mathrm{P}_{2}=15$ hari, $\mathrm{P}_{3}=20$ hari, $\mathrm{P}_{4}=25$ hari. Hasil sidik ragam menunjukkan lama pemeliharaan yang berbeda bepengaruh sangat nyata $(\mathrm{P}<0.01)$ terhadap berat, bahan kering dan panjang maggot. Disimpulkan bahwa hasil produksi maggot lalat tentara hitam Hermetia illucens paling baik pada perlakuan $\mathrm{P}_{4}$ yaitu berat 612,52 g dengan kadar bahan kering 30,47\% dan panjang 2,07 cm.
\end{abstract}

Keywords : Lalat tentara hitam,maggot.

\section{Pendahuluan}

Sektor pertanian mempunyai peranan yang sangat besar Pada tahun 2050 diperediksikan terjadi peningkatan populasi menjadi sembilan miliar orang, yang akan menghasilkan peningkatan permintaan daging sebesar 58\% dibandingkan tahun 2010 (FAO 2013). Ini akan membutuhkan peningkatan produksi ternak dan konsekuaesi yang harus diterima yaitu tekanan lingkungan akibat eksploitasi yang berlebihan. Hal tersebut berbanding lurus dengan penigkatan permintaan dan harga kedelai/ minyak sebagai bahan pakan, yang diperkirakan menyebabkan kenaikan harga daging > 30\% pada tahun 2050 dibandingkan tahun 2000 (FAO 2010). Oleh karena itu perlu dilakukan pencarian pakan alternative dan berkelanjutan. Pakan unggas harus mengandung semua nutrisi yang dibutuhkan untuk mendukung produksi dan pemeliharaan, sehingga dapat mengekspresikan potensi genetiknya. Oleh karena itu, studi pakan yang berkembang pada saat ini ditujukan untuk mencari sumber protein alternatif dengan memanfaatkan insekta.

Protein yang bersumber dari insekta lebih ekonomis dan ramah lingkungan serta mempunyai peran yang penting secara alamiah. Insekta dilaporkan memiliki efisiensi konversi pakan yang tinggi dan dapat dipelihara serta diproduksi secara massal (Q. Li et al. 2011). Selain itu insekta tidak berkompetisi dengan manusia sehingga sangat sesuai untuk digunakan sebagai bahan pakan ternak, termasuk unggas. Salah satu jenis insekta yang dapat digunakan yaitu lalat hitam (Hermetia illucens).

Maggot adalah organisme yang berasal dari telur lalat, pada metamorfosis fase kedua setelah fase telur dan sebelum fase pupa yang kemudian berubah menjadi lalat dewasa (Tomberlin, Adler, and Myers 2009). Maggot dapat mengkonversi material organik menjadi biomassanya. Keunggulan maggot adalah dapat diproduksi dalam berbagai ukuran, sesuai dengan kebutuhan (Fahmi et al. 2009). Kandungan protein maggot lalat tentara hitam cukup tinggi, yaitu $40-50 \%$ dengan kandungan lemak berkisar 29-32\% yang dapat dijadikan pakan (Bosch et al. 2014). Selain itu maggot memiliki organ penyimpanan yang disebut trophocytes yang berfungsi untuk menyimpan kandungan nutrient yang terdapat pada media kultur yang dimakannya (Subamia et al. 2010).

Berdasarkan hal tersebut maka penelitian ini dilakukan dengan lama pemeliharaan yang berbeda bertujuan untuk mengopimalkan produksi magoot meliputi ukuran maggot, berat basah dan berat kering

\section{Metodologi}

Penelitian ini dilaksanakan pada bulan April - Juli 2019. Pemeliharaan maggot lalat tentara hitam Hermetia illucens, Penelitan ini dilaksanakan di Program Studi Peternakan Unasman untuk pemeliharaan dan analisis nutrisi di laksanakan di Lab Kimia Pakan Fakultas Peternakan UNHAS.

Alat yang digunakan yaitu baskom, tali rapiah, kain kasa dan timbangan. Bahan yang digunakan yaitu feses ayam, ampas tahu, maggot Hermetia illucens.

Semua bahan untuk media tumbuh ditimbang dan dicampur yang beratnya $2,5 \mathrm{~kg}$ dengan persentase campuran $75 \%$ ampas tahu dan $25 \%$ feses ayam. Kemudian setiap media tumbuh ditambahkan 1 gr telur Hermetia illucens. Penelitian ini dirancang menggunakan 
Rancangan Acak Lengkap (RAL) 5 perlakuan yaitu lama pemeliharaaan maggot dan 3 ulangan. Secara keseluruhan menghasilkan 15 kombinasi perlakuan, yaitu $5 \times 3$ unit percobaan.

$$
\begin{aligned}
& \mathrm{P}_{0}=5 \text { hari } \\
& \mathrm{P}_{1}=10 \text { hari } \\
& \mathrm{P}_{2}=15 \text { hari } \\
& \mathrm{P}_{3}=20 \text { hari } \\
& \mathrm{P}_{4}=25 \text { hari }
\end{aligned}
$$

Data yang diperoleh dianalisis dengan menggunakan SPSS 24.

\section{Hasil Dan Pembahasan}

\section{Berat Magot}

Berat maggot lalat tentara hitam (Hermetia illucens) dengan lama pemeliharaan yang berbeda dapat dilihat pada Tabel 1 .

Tabel 1. Berat Maggot Lalat Tentara Hitam (Hermetia illucens) dengan Lama Pemeliharaan yang Berbeda (g)

\begin{tabular}{cccccc}
\hline \multirow{2}{*}{ Ulangan } & \multicolumn{5}{c}{ Perlakuan } \\
\cline { 2 - 6 } & $\mathrm{P}_{0}$ & $\mathrm{P}_{1}$ & $\mathrm{P}_{2}$ & $\mathrm{P}_{3}$ & $\mathrm{P}_{4}$ \\
\hline 1 & 295.04 & 442.04 & 631.40 & 683.24 & 627.72 \\
2 & 217.16 & 365.60 & 609.52 & 656.72 & 592.16 \\
3 & 282.08 & 454.32 & 590.84 & 703.68 & 617.68 \\
\hline $\begin{array}{c}\text { Rata- } \\
\text { rata }\end{array}$ & $264.76^{\mathrm{a}}$ & $420.65^{\mathrm{b}}$ & $610.59^{\mathrm{c}}$ & $681.21^{\mathrm{c}}$ & $612.52^{\mathrm{d}}$ \\
\hline
\end{tabular}

Keterangan: Huruf Yang Berbeda pada Superscript Angka Rata - Rata Berbeda Sangat Nyata $(\mathrm{P}<0.01)$.

Berdasarkan sidik ragam lama pemeliharan maggot lalat tentara hitam (Hermetia illucens) berpengaruh sangat nyata $(\mathrm{P}<0.01)$ terhadap berat maggot. Berdasarkan table 1 menunjukkkan setiap perlakuan cenderung mengalami peningkatan kadar protein kasar.

Hasil uji Duncan protein kasar menunjukkan bahwa $\mathrm{P}_{0}$ berbeda sangat nyata terhadap $\mathrm{P} 1, \mathrm{P} 2, \mathrm{P}_{3}$ dan $\mathrm{P}_{4}$ $(\mathrm{P}<0.01)$. Perlakuan $\mathrm{P} 1$ berbeda sangat nyata dengan $\mathrm{P}_{2}$, $\mathrm{P}_{3}$ dan $\mathrm{P}_{4}(\mathrm{P}<0.01)$. Perlakaun $\mathrm{P}_{2}$ berbeda nyata dengan $\mathrm{P}_{4}$ $(\mathrm{P}<0.05)$ tetapi tidak berbeda nyata dengan $\mathrm{P}_{3}(\mathrm{P}>0.05)$. Perlakauan $\mathrm{P}_{3}$ berbeda nyata dengan $\mathrm{P}_{4}(\mathrm{P}<0.01)$.

Berat maggot cenderung meningkat karena maggot bertambah besar baik dari ukuran panjang maupun lebar pada perlakuan $\mathrm{P}_{1}, \mathrm{P}_{2}$, dan $\mathrm{P}_{3}$, akan tetapi pada perlakuan $\mathrm{P}_{4}$ mengalami penurunan berat dikarenakan maggot sedang memasuki pra pupa. Hasil Perkembangan maggot Hermetia illucens yaitu waktu 2-4 hari telur akan menetas menjadi maggot instar satu dan berkembang hingga ke instar enam dalam waktu 22-24 hari dengan rata-rata 18 hari. Ditinjau dari ukurannya, maggot yang baru menetas dari telur berukuran kurang lebih $2 \mathrm{~mm}$, kemudian berkembang hingga $5 \mathrm{~mm}$. Setelah terjadi pergantian kulit, maggot berkembang dan tumbuh lebih besar dengan panjang tubuh mencapai 20-25 mm, kemudian masuk ke tahap prepupa (Barros-Cordeiro, Bao, and Pujol-Luz 2014).

\section{Bahan kering}

Bahan kering maggot lalat tentara hitam Hermetia illucens dengan lama pemeliharaan yang berbeda dapat dilihat pada Tabel 2.

Tabel 2. Bahan kering Maggot Lalat Tentara Hitam (Hermetia illucens) dengan Lama Pemeliharaan yang Berbeda (\%)

\begin{tabular}{cccccc}
\hline \multirow{2}{*}{ Ulangan } & \multicolumn{5}{c}{ Perlakuan } \\
\cline { 2 - 6 } & $\mathrm{P}_{0}$ & $\mathrm{P}_{1}$ & $\mathrm{P}_{2}$ & $\mathrm{P}_{3}$ & $\mathrm{P}_{4}$ \\
\hline 1 & 23.61 & 23.91 & 21.09 & 24.03 & 28.75 \\
2 & 21.00 & 27.12 & 24.95 & 27.38 & 29.99 \\
3 & 21.34 & 22.77 & 30.63 & 25.84 & 32.68 \\
\hline $\begin{array}{c}\text { Rata- } \\
\text { rata }\end{array}$ & $21.98^{\mathrm{a}}$ & $24.60^{\mathrm{b}}$ & $25.56^{\mathrm{c}}$ & $25.75^{\mathrm{cd}}$ & $30.47^{\mathrm{d}}$ \\
\hline
\end{tabular}

Keterangan: Huruf Yang Berbeda pada Superscript Angka Rata-Rata Berbeda Sangat Nyata $(\mathrm{P}<0.01)$.

Beradasarkan sidik ragam lama pemeliharaan yang berbeda pada maggot lalat tentara hitam (Hermetia illucens) berpengaruh sangat nyata $(\mathrm{P}<0.01)$ terhadap berat kering. Pada Tabel 2 menunjukkan mengalami peningkatan dari lama pemeliharaan 5 hari $\left(\mathrm{P}_{0}\right)$ sampai pemeliharaan 25 hari $\left(\mathrm{P}_{4}\right)$. Hal tersebut menunjukkan bahan kering berbanding lurus dengan lama pemeliharaan.

Hasil uji Duncan menunjukkan bahwa perlakuan $\mathrm{P}_{0}$ berbeda nyata $(\mathrm{P}<0.01)$ dengan $\mathrm{P}_{1}, \mathrm{P}_{2}, \mathrm{P}_{3}$, dan $\mathrm{P}_{4}$. $\mathrm{P}_{1}$ berbeda nyata $(\mathrm{P}<0.01)$ dengan $\mathrm{P}_{2}, \mathrm{P}_{3}$ dan $\mathrm{P}_{4}$. Perlakuan $\mathrm{P}_{2}$, tidak berbeda nyata $(\mathrm{P}>0.05)$ dengan $\mathrm{P}_{3}$, tetapi berbeda sangat nyata dengan $\mathrm{P}_{4}(\mathrm{P}<0.01)$. Perlakuan $\mathrm{P}_{3}$ tidak berbeda nyata $(\mathrm{P}>0.05)$ dengan $\mathrm{P} 4$.

Peningkatan bahan kering setiap perlakuan disebabkan maggot memakan nutrisi media dan dikonversi dalam tubuhnya. Semakin lama pemelihaharaan semakin banyak media dimakan dan mengkonversi nutrisi media dalam tubuh. Hal tersebut sesuai dengan (Mujahid, Amin, and A. Hariyadi 2017) bahwa Berat larva akan bertambah dari berat awal $5 \mathrm{~g}$ menjadi 230,34 g dalam waktu 8 hari. TKKS yang terkonversi menjadi larva yaitu rata-rata 39\%. (A. H. Wardhana 2016) Persentase komponen nutrisi maggot Hermetia illucens berdasarkan kadar bahan kering yaitu cenderung berkorelasi positif dengan meningkatnya umur. Pada umur lima hari 26,61\% dan menjadi 39,97\% pada umur 25 hari. Hal yang sama juga terjadi pada komponen lemak kasar, yaitu sebesar $13,37 \%$ pada umur lima hari dan meningkat menjadi $27,50 \%$ pada umur 25 hari.

\section{Panjang Magot}

Panjang maggot lalat tentara hitam Hermetia illucens dengan lama pemeliharaan yang berbeda dapat dilihat pada Tabel 3. 
Tabel 3. Ukuran Panjang Maggot Lalat Tentara Hitam (Hermetia illucens) dengan Lama Pemeliharaan yang Berbeda $(\mathrm{cm})$

\begin{tabular}{cccccc}
\hline \multirow{2}{*}{ Ulangan } & \multicolumn{5}{c}{ Perlakuan } \\
\cline { 2 - 6 } & $\mathrm{P}_{0}$ & $\mathrm{P}_{1}$ & $\mathrm{P}_{2}$ & $\mathrm{P}_{3}$ & $\mathrm{P}_{4}$ \\
\hline 1 & 1.3 & 23.91 & 21.09 & 24.03 & 28.75 \\
2 & 1.5 & 27.12 & 24.95 & 27.38 & 29.99 \\
3 & 1.5 & 22.77 & 30.63 & 25.84 & 32.68 \\
\hline $\begin{array}{c}\text { Rata- } \\
\text { rata }\end{array}$ & $1.43^{\mathrm{a}}$ & $1.83^{\mathrm{b}}$ & $2.03^{\mathrm{bc}}$ & $2.03^{\mathrm{bc}}$ & $2.07^{\mathrm{cd}}$ \\
\hline
\end{tabular}

Keterangan : Huruf Yang Berbeda pada Superscript Angka Rata-Rata Berbeda Sangat Nyata $(\mathrm{P}<0.01)$.

Beradasarkan sidik ragam lama pemeliharaan yang berbeda pada maggot lalat tentara hitam (Hermetia illucens) berpengaruh sangat nyata $(\mathrm{P}<0.01)$ terhadap panjang magot. Pada Tabel 2 menunjukkan panjang maggot cenderung meningkat berbanding lurus dengan umur.

Hasil uji Duncan menunjukkan bahwa perlakauan $\mathrm{P}_{0}$ berbeda nyata $(\mathrm{P}<0.01)$ dengan $\mathrm{P}_{1}, \mathrm{P}_{2}, \mathrm{P}_{3}$, dan $\mathrm{P}_{4} . \mathrm{P}_{1}$ tidak berbeda nyata $(\mathrm{P}>0.05)$ dengan $\mathrm{P}_{2}$, dan $\mathrm{P}_{3}$ tetapi berbeda sangat nyata $(\mathrm{P}<0.01)$ dengan $\mathrm{P}_{4}$. Perlakuan $\mathrm{P}_{2}$, tidak berbeda nyata $(\mathrm{P}>0.05)$ dengan $\mathrm{P}_{3}$, dan $\mathrm{P}_{4}$. Perlakuan $\mathrm{P}_{3}$ tidak berbeda nyata $(\mathrm{P}>0.05)$ dengan $\mathrm{P} 4$.

Peningkatan bahan kering setiap perlakuan disebabkan perkembangan maggot yaitu umur 0 hari sampai 20 hari maggot mengalami pertumbuhan. (Fahmi et al. 2009) Pertambahan panjang dan lebar maggot mengalami peningkatan hingga umur 20 hari. Ukuran maksimal maggot mencapai $25 \mathrm{~mm}$ untuk panjang dan 5 mm untuk lebar. Sedangkan ukuran maggot berdasarkan umur sebagai berikut, umur 2-4 hari maggot memiliki panjang tubuh 2-5 $\mathrm{mm}$ dan lebar 0,4-1 $\mathrm{mm}$, umur 6-9 hari memiliki ukuran panjang 5-10 mm dan lebar 1-2,5 $\mathrm{mm}$, umur 10-13 hari memiliki ukuran panjang 10- 15 $\mathrm{mm}$ dan lebar 2-3 $\mathrm{mm}$, dan ukuran maksimal maggot dicapai setelah 20 hari yaitu panjang 20-25 mm dan lebar $5 \mathrm{~mm}$. Berdasarkan grafik pertumbuhan tersebut maka produksi maggot ukuran tertentu dapat dilakukan. Setelah mendapatkan maggot sesuai dengan ukuran yang diinginkan, maka dilakukan pemanenan

\section{Kesimpulan}

Berdasarkan analisa data dapat disimpulkan produksi maggot lalat tentara hitam Hermetia illucens paling baik pada perlakuan $\mathrm{P}_{4}$ yaitu berat $612,52 \mathrm{~g}$ dengan kadar bahan kering $30.47 \%$ dan panjang $2.07 \mathrm{~cm}$.

\section{Daftar Pustaka}

A. H. Wardhana. 2016. "Black Soldier Fly ( Hermetia Illucens ) Sebagai Sumber Protein Alternatif Untuk Pakan Ternak." Wartazoa 26(2): 69-78

Barros-Cordeiro, K., S. Nair Bao, and J. Pujol-Luz. 2014. "IntraPuparial Development of TheBlack Soldier Fly (Hermetia Illucens)." J Insect Sci 14: 1-10.

Bosch, G., S. Zhang, G. Dennis, and H. Wouter. 2014. "Protein Quality of Insects as Potential Ingredients for Dog and Cat Foods." $J$ Nutr Sci 3(1-4).

Fahmi, R., S. Melta, W Hem, and I W.Subamia. 2009. "Potensi Maggot
Untuk Peningkatan Pertumbuhan Dan Status Kesehatan Ikan.” J. Ris. Akuakultur 4(2): 221-32.

FAO. 2010. The State of World Fisheries and Aquaculture. Italy: Rame.

2013. Edible Insects Future Prospects for Food and Feed Security. Italy: Rame.

Mujahid, M. R. F., A. Amin, and A. Hariyadi. 2017. "Biokonversi Tandan Kosong Kelapa Sawit Menggunakan Trichoderma Sp . Dan Larva Black Soldier Fly Menjadi Bahan PakanUnggas.” J. Ilmu Produksi dan Teknol. Has. Peternak. 5(1): 5-10.

Q. Li, L et al. 2011. "Bioconversion of Dairy Manure by Black Soldier Fly (Diptera: Stratiomyidae) for Biodiesel and Sugar Production." J.Wasman 31(6): 1316-1320.

Subamia, I W, B. Nur, A. Musa, and R. V Kusumah. 2010. "Manfaat Maggot Yang Dipelihara Dengan Zat Pemicu Warna Sebagai Pakan Untuk Peningkatan Kualitas Warna Ikan Rainbow (Melanotaenia Boesmani) Asli Papua."

Tomberlin, J K, P H Adler, and H M Myers. 2009. "Development of the BlackSoldier Fly (Diptera: Stratiomyidae)in Relation to Temperature." Environ Entomol 38(3): 930-934. 
